\begin{tabular}{l|l}
4 & -24 \\
\hline
\end{tabular}

4hating

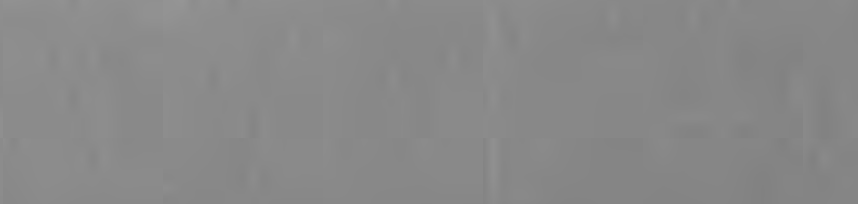

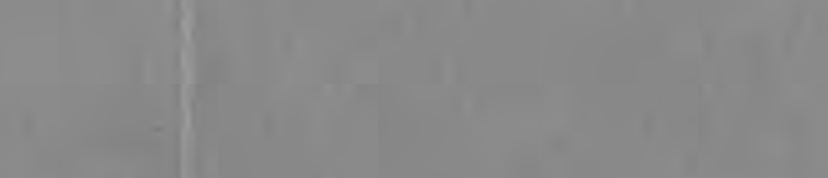

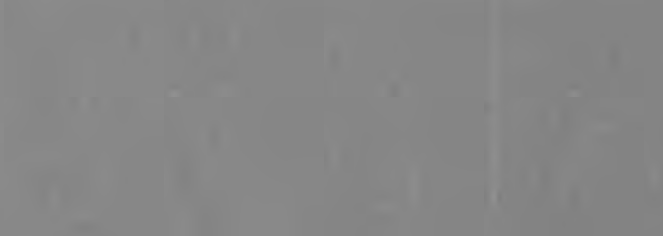

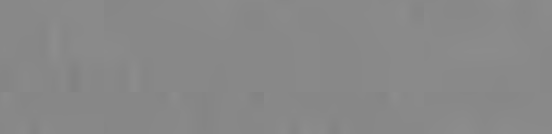

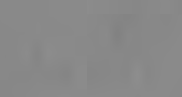
$x^{2}+1=12$ $1+1$

1.

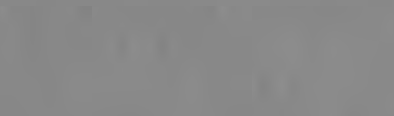
anting

$-1+1$ inting

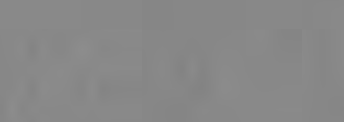

$x^{2}+x^{2}$ (1)

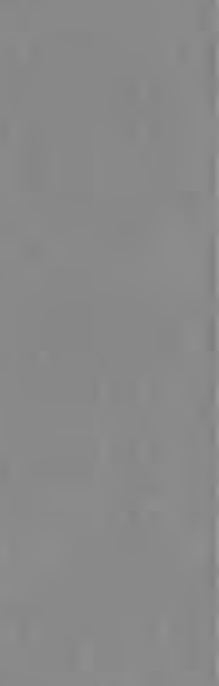

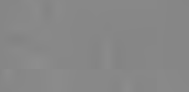

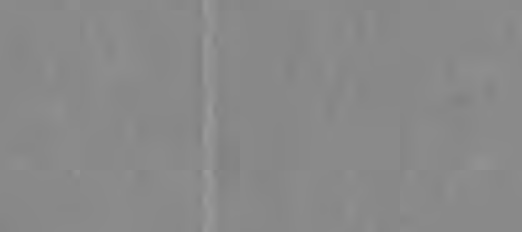

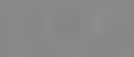

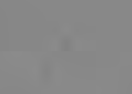

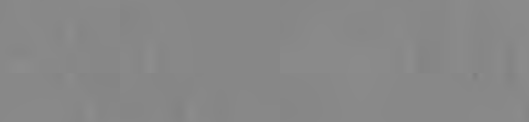

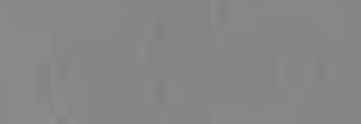

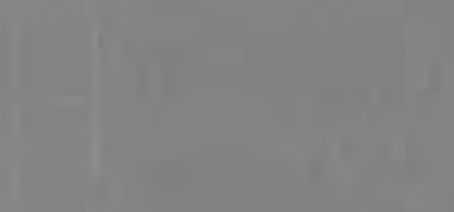
titi

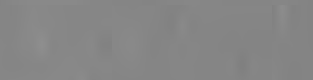

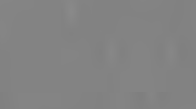
.

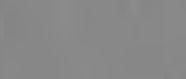

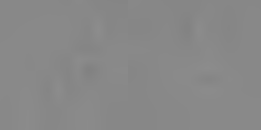

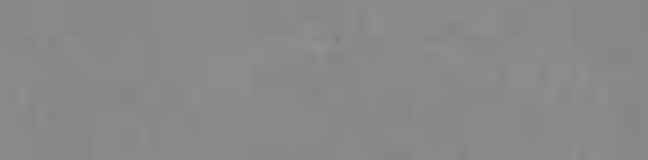

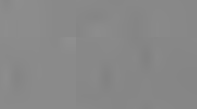

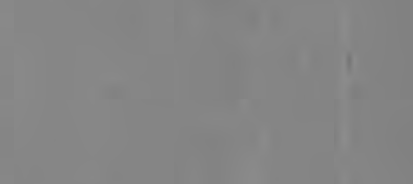

|

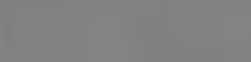<smiles>C=CC</smiles>

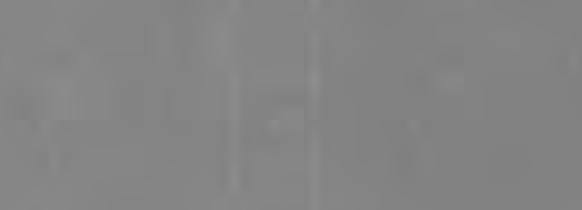

11

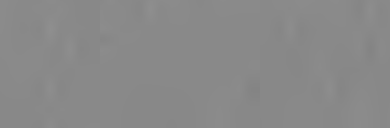

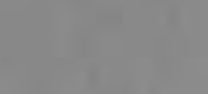

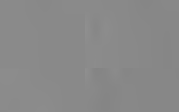

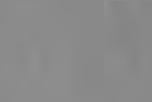

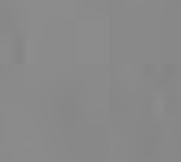

$x^{4}+18$

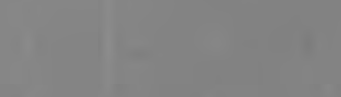

$(1+1)$

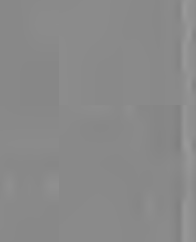

17+1

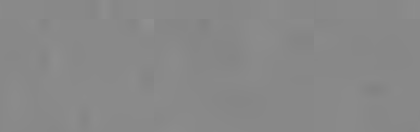

$(1+1$

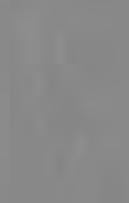

itis

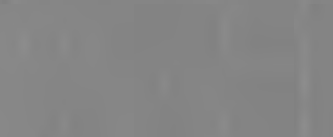

(i)

(1)

and

(4)

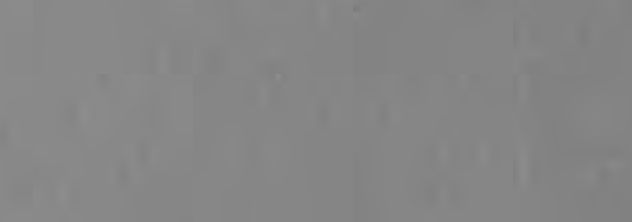

in (1)

(7) $17=$

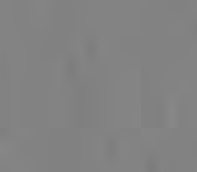

$y=1=$ i. 
UNITED STATES DEPARTMENT OF THE INTERIOR

Douglas McKay, Secretary

GEOLOGICAL SURVEY

W. E. Wrather, Director

GEOLOGICAL SURVEY CIRCULAR 328

RECONNAISSANCE FOR RADIOACTIVE DEPOSITS IN THE LOWER YUKON-

KUSKOKWIM REGION, ALASKA, 1952

By Walter S. West

This report concern. work done on

behalf of the U. S. Atomic Energy

Commission and is published with

the permission of the Commission. 



\title{
RECONNAISSANCE FOR RADIOACTIVE DEPOSITS IN THE LOWER YUKON- KUSKOKWIM REGION, ALASKA, 1952
}

\author{
By Walter S. West
}

CONTENTS

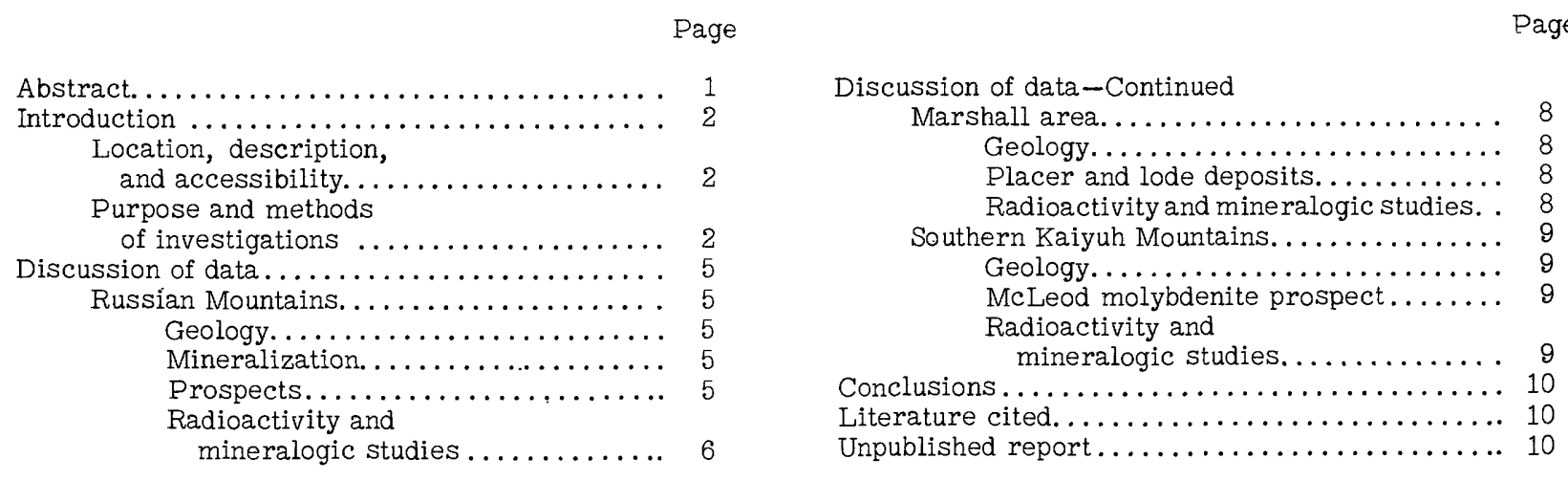

ILLUSTRATIONS

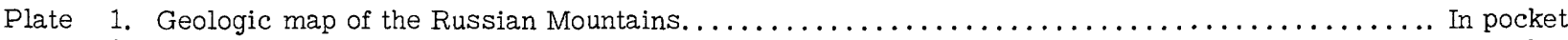

2. Geologic sketch map of the Marshall area ............................ In pocket

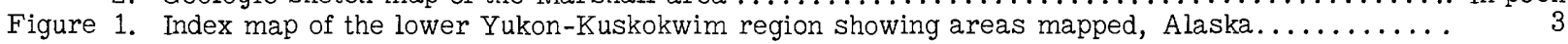

2. Topographic map of part of the Unalakeet quadrangle, west-central Alaska, showing location of McLeod molybdenite prospect.............

TABLES

Page

Table 1. Equivalent uranium analyses of samples from the Russian Mountains, Alaska............ 6

2. Mineralogy of heavy-mineral fractions

(those greater than 3.3 specific gravity) of selected samples.................

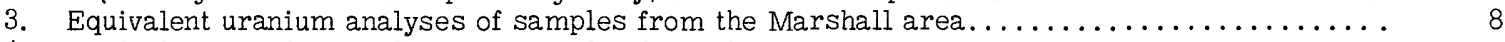

4. Equivalent uranium analyses of samples from the

McLeod molybdenite prospect, southern Kaiyuh Mountains.................. 10

\begin{abstract}
Reconnaissance in the lower Yukon-Kuskokwim region during 1952 consisted of an examination for radioactivity of a metazeunerite occurrence in the Russian Mountains and molybdenite occurrences in the Marshall area and in the southern Kaiyuh Mountains.

Metazeunerite, a hydrous copper-uranium arsenate, was identified in a concentrate of arseniccopper vein material which was collected in the upper tunnel of the Konechney prospect in the Russian Mountains in 1944 when mineralogic studies of several
\end{abstract}

samples from this area were made in 1948. Although the underground workings were not accessible in 1952, a trace amount of metazeunerite was found in a sample from the ore dump of this same tunnel. No other occurrences of uranium minerals were found. The oxidizing and highly acid environment of the ore dumps and bedrock outcrops in the Russian Mountains could account for the scarcity of secondary uranium minerals and the absence of primary uranium minerals near the surface. If so, the trace amounts of metazeunerite that have been found may indicate that larger amounts of secondary uranium minerals occur at greater depths and possibly grade downward into significant deposits of primary uranium minerals. The maximum 
equivalent uranium content of the samples collected during 1952 in this area is 0.004 percent.

No uranium deposits of commercial importance were found in the Marshall and southern Kaiyuh Mountains area. Samples collected in the Marshall area contain 0.001 percent or less equivalent uranium. The vein material at the McLeod molybdenite prospect in the southern Kaiyuh Mountains shows less than 0.001 percent equivalent uranium and the rhyolite porphyry country rock contains 0.003 percent equivalent uranium.

\section{INTRODUCTION}

\section{Location, description, and accessibility}

Radioactivity examinations in the lower YukonKuskokwim region, Alaska, were made in the Russian Mountains, the Marshall area, and at the McLeod molybdenite prospect in the southern Kaiyuh Mountains from mid-July to mid-August 1952.

The Russian Mountains comprise an isolated group of rugged peaks in the Kuskokwim Mountain belt centering about 15 miles northeast of Aniak on the Kuskokwim River and 45 miles south of Holy Cross on the Yukon River (fig. 1). They are bounded on the south by the Kuskokwim River; on the wast and north by the Owhat River; and on the east by the Kolmakof River (pl. 1). This group of mountains has an extent of about 10 miles both from east to west and from north to south. The central peaks range in altitude from 4,000 to 4,500 feet, contrasting sharply in relief with the flanking well-rounded ridges and sloping spurs that range in altitude from 1,000 to 2,000 feet and the broad valleys of the Kuskokwim, Owhat, and Kolmakof Rivers. Striking topographic features in the rugged part of the Rusisian Mountains are the knife-edge ridges, steep talus-covered slopes scarred by many rock slides, precipitous-walled cirques, hanging valleys, and steepsided U-shaped valleys.

The Russian Mountains are not easily accessible. An airfield at Aniak which is maintained by the Civil Aeronautics Authority will accommodate multiengine planes. Single-engine aircraft may land on a bar in the Kuskokwim River near Napaimiut. The Kuskokwim River is navigable for shallow-draft boats, tugs, and barges that bring most of the heavy freight up the river from Bethel, 100 miles southwest of Aniak. A winter sled trail along the Kuskokwim River from Napaimiut follows the valley of Sutter Creek, a tributary to Kolmakof River, and swings around the northeast end of the Russian Mountains into lower Cobalt Creek, a tributary to Owhat River. This trail is about 28 miles long. A similar trail, about 12 miles long, extends from Little Russian Mission to the headwaters of Mission Creek, a south-flowing tributary to the Kuskokwim River.

The central part of the Marshall area lies on an east-trending divide between Wilson and Spruce Creeks, tributaries to the Yukon River, about 8 miles east southeast of Marshall and 75 miles southwest of Holy Cross (fig. 1). This divide is a well-rounded tundra covered upland having sparce rock outcrops and scattered patches of rock talus. Its maximum altitude is 1,780 feet. Pilcher Mountain (altitude, about 2,000 feet),
$4 \frac{1}{2}$ miles northeast of Marshall, is the highest and most conspicuous peak in the area.

The Marshall area is accessible by single-engine planes that may land on any one of four small airfields (pl. 2). Two of these airfields are located at Marshall; a third is near the mouth of Disappointment Creek, a tributary to Wilson Creek; and a fourth is near the junction of the two main headwater forks of Willow Creek, a tributary to Spruce Creek. The airstrip on Disappointment Creek although abandoned appeared to be in the best condition in 1952. Amphibious and floattype aircraft may land on the Yukon River at Marshall and elsewhere in the area. Most of the heavy freight is brought up the Yukon River by boats, tugs, and barges. A tractor trail originating at Marshall follows up Wilson Creek via the airfield on Disappointment Creek to Elephant Creek where it crosses the divide to the mining camp and airfield on Willow Creek. A road extends from the mining camp on Willow Creek to The Landing, $7 \frac{1}{2}$ miles southeast of Marshall.

The McLeod molybdenite prospect in the southern Kaiyuh Mountains is about 90 miles north-northeast of Holy Cross, 65 miles southeast of Unalakleet, and 70 miles south of Kaltag (fig. 1). The deposit is on a low ridge about 14 miles east of the lower end of the largest island in the Yukon River in this vicinity (fig. 2). Most of the hills near this prospect are covered with vegetation. Bedrock outcrops are scarce. Rock talus occurs on some of the steeper slopes and hilltops. There are no roads or airfields in this part of the Kaiyuh Mountains. However, single-engine planes may land on a bar along the east bank of the Yukon River about 6 miles downstream from the large island mentioned above. A point 6 or 7 miles northwest of the McLeod prospect may be reached by small boat.

\section{Purpose and methods of investigations}

Mineralogic studies by Moxham (1950) in 1948 of samples collected in the Russian Mountains by R. E. Wallace and E. J. Webber of the Geological Survey in 1944 disclosed traces of metazeunerite in a radioactive concentrate of arsenic-copper vein material from the upper tunnel of the Konechney claims. Because the zeunerite (now called metazeunerite) may be indicative of the presence of primary uranium minerals, a field investigation of this area appeared to be warranted.

Reconnaissance examinations were made in the Marshall and southern Kaiyuh Mountains area because they were known to contain lode deposits having mineral assemblages similar to uranium deposits in other parts of the world. A proposed investigation of a silver-lead deposit in the northern Kaiyuh Mountains could not be accomplished because of the lack of transportation facilities.

The 1952 investigations were made by Walter.S. West, geologist, and George M. Haselton, geologic field assistant. This work was done on behalf of the Division of Raw Materials of the U. S. A tomic Energy Commission. Helicopter and light-plane support for the work was furnished by the U. S. Army, 30th Engineer Base Topographic Battalion, with Forward Echelon Headquarters at Unalakleet. The Russian Mountains and 


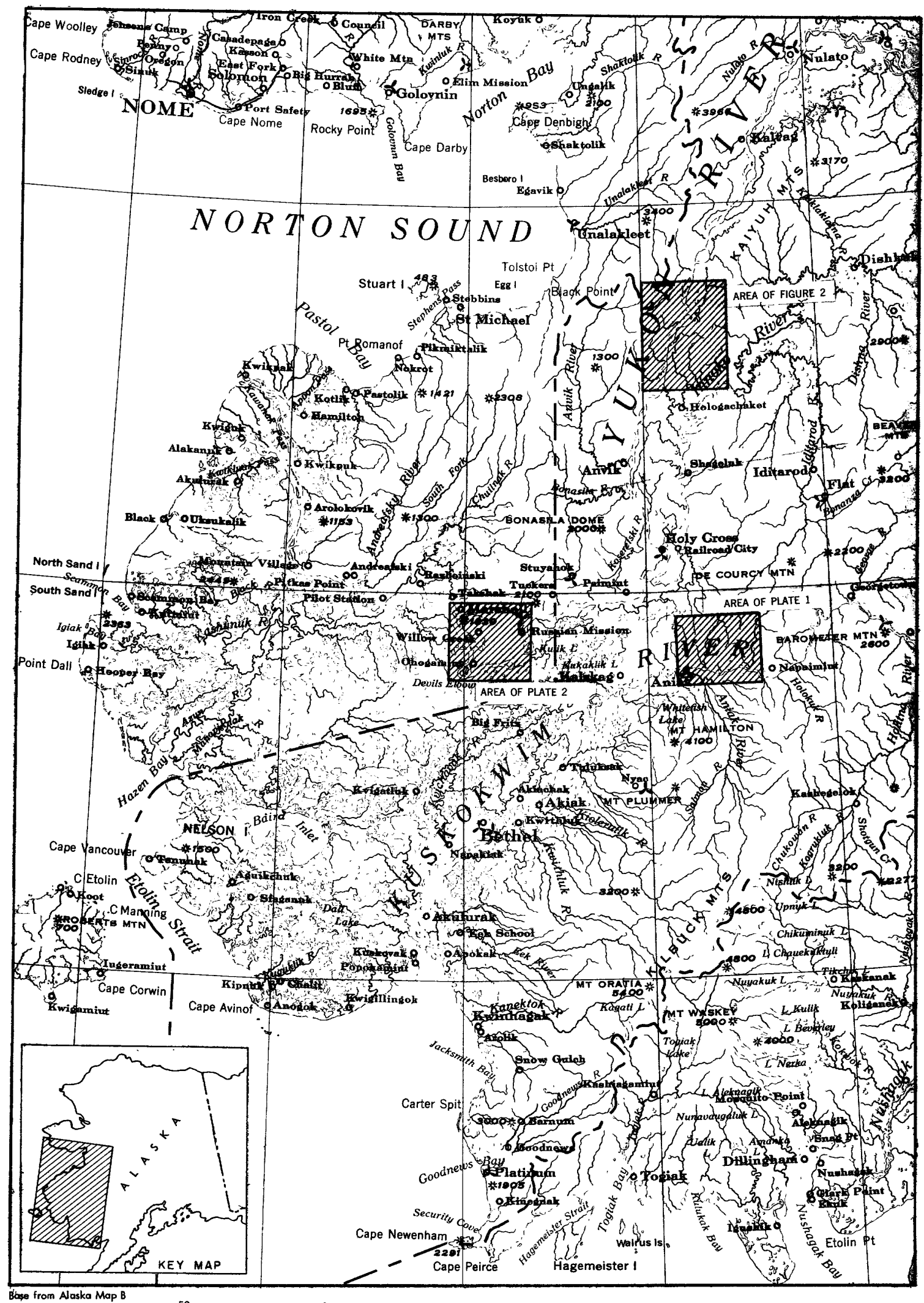

$50+0$ 150 Miles

Figure 1. - Index map of the lower Yukon-Kuskokwim region showing areas mapped, Alaska. 


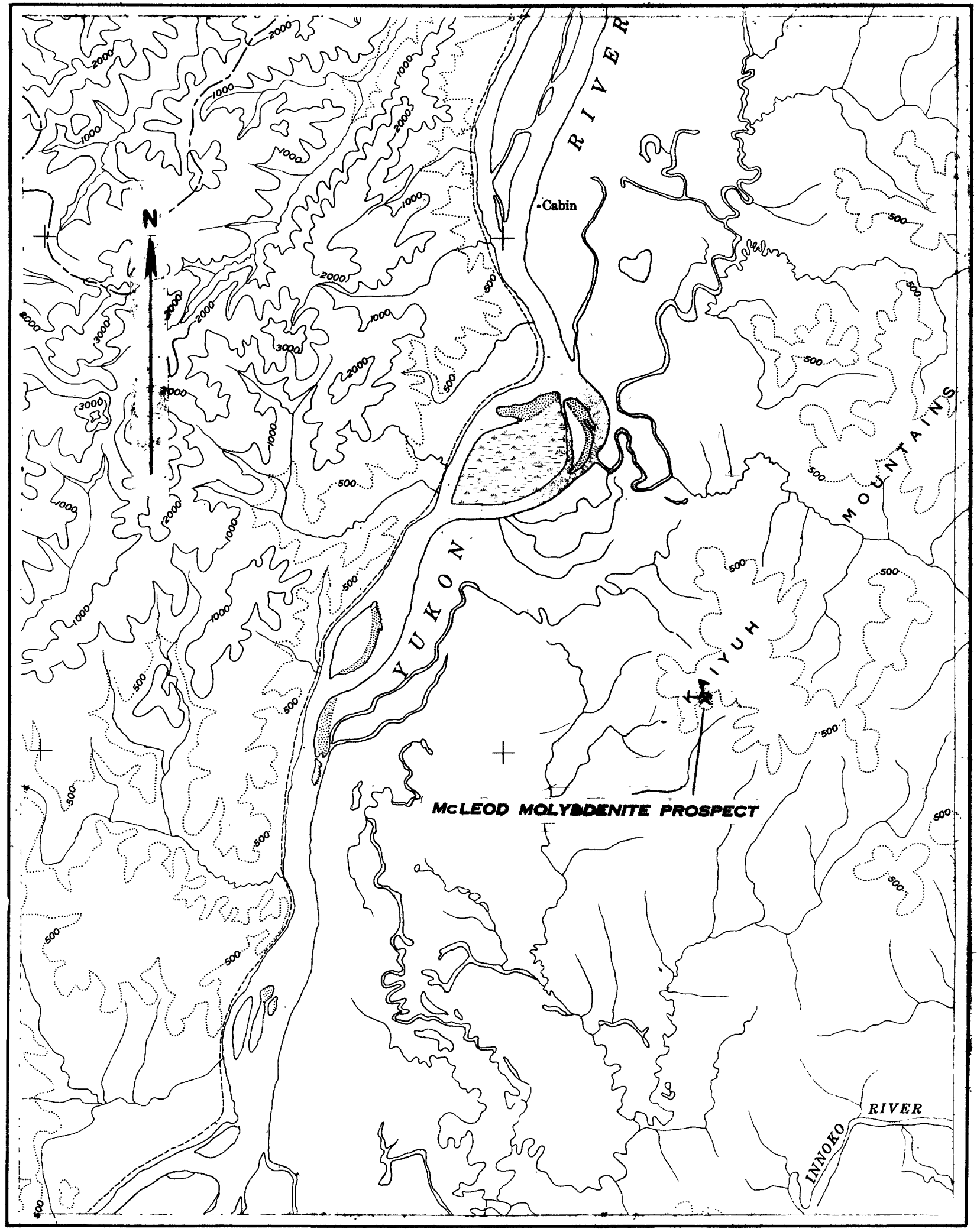

5

s

15

20! MILES

Figure 2. - Topographic map of part of the Unalakeet quadrangle, west-central Alaska, showing location of McLeod molybdenite prospect. 
Marshall area were worked from the 30th Engineer's field camp at Holy Cross. The southern Kaiyuh Mountains area was covered from the 30th Engineer's field camp on the east bank of the Yukon River 55 miles southeast of Unalakleet.

Field investigations in the three areas consisted of airborne radioactivity traversing and traversing by foot and the collecting of rock and mineral samples. Walking traverses were made with standard commercial models of portable survey meters equipped with 2 - by 20-inch gamma probes mounted on packboards. Individual talus blocks, ore specimens, veins, dikes, and some bedrock outcrops were tested with 6-inch beta probes. A gang of three 2 - by 40 -inch gamma probes attached to standard survey meters was used for airborne traversing with light planes and helicopters.

All equivalent uranium analyses and most of the mineralogic determinations of the samples were made by personnel of the Alaskan Trace Elements Unit at the Geological Survey's Fairbanks testing laboratory at College, Alaska, and at Washington, D. C. Several X-ray analyses were made in the laboratories of the Geological Survey, Washington, D. C.

\section{DISCUSSION OF DATA}

\section{Russian Mountains}

\section{Geology}

The geology of the Russian Mountains has been described by Maddren (1915) and Moxham (1950). The geology is shown on plate 1 .

A felsic stock that probably was intruded in either Cligocene or early Miocene time is exposed in the high central part of the Russian Mountains. The chief components of the stock are quartz monzonite of porphyritic character and granite with more mafic material occurring as a border phase of the intrusive rock mass. Mafic and felsic dikes probably related genetically to the stock occur in the stock and in the adjoining country rock. A narrow and somewhat discontinuous belt of Tertiary basalt is found adjacent to the stock. The highlands that surround the central intrusive and extrusive igneous mass are made up of metamorphosed graywacke and slate of Cretaceous age grading into the sedimentary series of graywackes, sandstones, and shales that form the greater part of the Kuskokwim Mountains. The valley floors and lowlands are covered with a mantle of glacial deposits, outwash, and alluvium.

\section{Mineralization}

The stock and genetically related dikes in the Russian Mountains have been rather highly mineralized and several lode deposits of metallic sulfides were found.

After the emplacement of the intrusive igneous rocks, ore-forming solutions were apparently injected along major joints and shear zones that strike northwesterly across the stock and dip steeply to the southwest. The solutions deposited minerals in the form of fissure veins and breccia fillings. To a lesser extent ore minerals occur disseminated in the igneous country rocks.

The lode deposits are mainly composed of arsenopyrite, chalcopyrite, pyrite, pyrrhotite, and hematite with small amounts of galena, sphalerite, chalcocite, native copper, and scheelite being present at some localities. According to reported assays, the ore shows minor amounts of gold, silver, and tin. In the zone of weathering the ore has been partly altered to scorodite, limonite, goethite, azurite, malachite, cuprite, and chrysocolla. The principal gangue mineral is quartz.

\section{Prospects}

Rather extensive prospecting for 'copper and other minerals has been done at two localities in the Russian Mountains.

One of these localities, the Konechney prospect (sample localities 1734, 3267, 4650, and 4653 , pl. 1), was discovered in 1920 by Joe Konechney of Aniak and has been developed by him almost continuously since that time until a few years ago. The prospect is situated at and above the headwaters of Mission Creek at an altitude of about 2,000 to 2,350 feet. The workings consist of two tunnels that total about 900 feet of underground excavation and several surface pits and trenches. The portal of the upper adit is now covered by a rock slide, the lower adit is completely iced shut near the portal, and the surface pits and trenches have slumped and are partly filled with rock talus. The development work has explored a mineralized zone about 200 feet wide for a distance of 1,000 feet along the surface trace. The mineralized zone consisting of quartz veins and thin layers of breccia and gouge, occurs in quartz monzonite and nearly vertical basaltic dikes that strike N. $25^{\circ} \mathrm{W}$. The orientation of the mineral deposits is the same as that of the dikes. According to reported assays, the ore has an average content of 1.0 percent copper, and 0.1 ounce of gold and 1.0 ounce of silver per ton.

The other locality is in the upper basin of Cobalt Creek near the head of the east headwater fork and a little more than a mile north-northeast of the Konechney prospect. The Cobalt Creek prospect (sample localities 3269,3270 , and 4663-4669, pl. 1), which was discovered about 1900 and comprises four claims collectively known as the February group, lies at an altitude of about 1,550 to 1,750 feet. The workings consist of three shallow shafts and several surface trenches and pits. At the time of the writer's visit the greater part of the workings had become filled with rock debris. The development work had explored about 800 feet along the strike of a vein deposit of the fissure type and associated mineralized breccia zones that may be traced by surface croppings for a distance of about 4,000 feet. The mineral deposits occur in quartz monzonite. The vein which strikes N. $25^{\circ} \mathrm{W}$. and dips $80^{\circ} \mathrm{SW}$ ranges in width from 5 feet to 30 inches and 
appears to average about 3 feet in width to a depth of 40 feet, the maximum reported depth attained by a. shaft near the north end of its outcrop. The ore contains copper, gold, and silver. The copper, in the form of chalcopyrite, is said to increase in amount with depth. An ore sample from the dump of one of the shafts is reported to have assayed 11.0 percent copper, less than 0.25 ounces of gold per ton, and traces of silver. Assays of two samples from a shallow shaft about 1,000 feet west of the fissure vein mentioned above are reported to show the presence of 1.22 and 1.40 percent tin.

Probably other mineralized zones in the Russian Mountains have been prospected to some extent although no workings were observed beyond the limits of the Konechney and February groups of claims. One of these additional mineralized zones trends northwesterly across the crest of the ridge between the Konechney and Cobalt Creek prospects, and another occurs on the northwest slope of the divide between Mission and Cobalt Creeks east of the Konechney prospect. Possibly more detailed investigations would reveal other occurrences of lode mineralization.

Placer gold has been reported in the gravels of Mission Creek. Some of this gold was probably derived from zones of mineralization in or near the contact of the intrusive igneous rocks at the head of the stream.

\section{Radioactivity and mineralogic studies}

Airborne radioactivity traversing in the Russian Mountains was accomplished with a U. S. Army L-19 plane. Adverse weather conditions limited the traverse to the lower altitudes in the mountains, and only a small part of the intrusive igneous rock mass along Mission Creek could be covered by the flight. A considerable amount of the area north and east of the mountains was traversed during the same flight which originated at and returned to Holy Cross on the Yukon River. Part of the area south and west of the mountains was covered on a continuation of the flight to Aniak.

Radioactivity traversing on foot was essentially confined to the intrusive igneous mass in the vicinity of the Konechney and Cobalt Creek claims. As previously pointed out in the discussion of the prospects, none of the bedrock and mineral deposits in the underground and surface workings were accessible for study. However, the ore dumps from the workings were carefully traversed and many individual rocks and ore specimens on the dumps were scanned with 6-inch beta probes.

Neither airborne nor walking traverses disclosed the presence of any significant radiation anomalies. However, they did show that the intrusive igneous rocks were more radioactive than the other types of rocks in the Russian Mountains.

Equivalent uranium determinations were made on 14 of the rock and mineral samples collected in the Russian Mountains during the 1952 investigation. Equivalent uranium analyses of these samples (nos. 4647, $4648,4650-4653$, and 4662-4669) and 7 samples collected by R. E. Wallace and E. J. Webber in 1944 (nos. 1734 and 3266 through 3271 ) are given in table 1. The equivalent uranium determinations listed in table 1 were made on unconcentrated crushed rock and vein material. The locations of the samples are shown on plate 1 .

As shown in table 1, the samples collected in 1944 contain from 0.002 to 0.006 percent equivalent uranium. The equivalent uranium content of the 1952 samples ranges from less than 0.001 to 0.004 percent with the quartz monzonite bedrock samples having the largest content. The relatively low percent of equivalent uranium in the samples substantiates the results obtained by airborne and walking radioactivity

Table 1.-Equivalent uranium analyses of samples from the Russian Mountains, Alaska

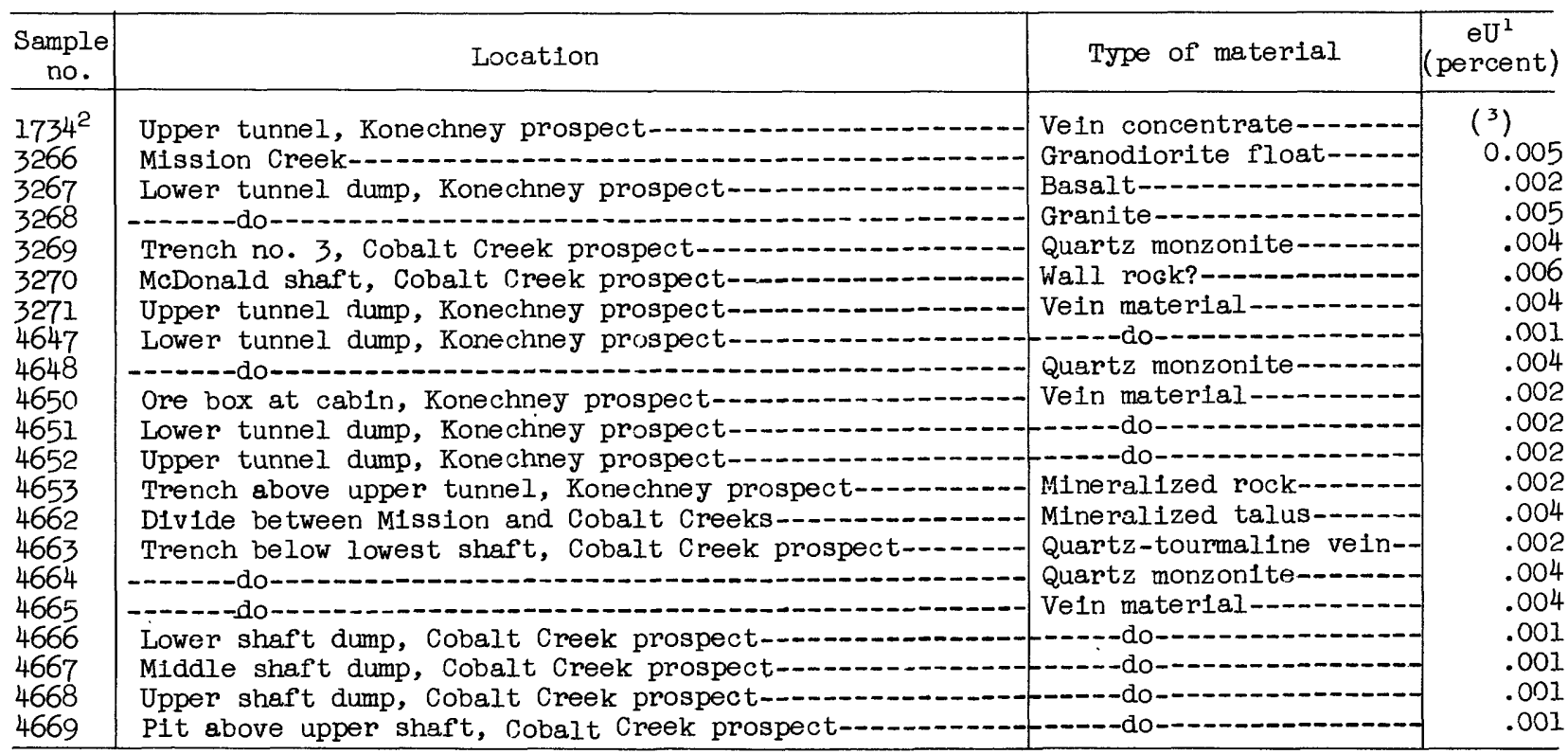


traverses, namely, that no highly radioactive deposits were detected at or near the surface in the part of the area which was subjected to study.

Additional radioactivity and mineralogic examinations of the 1952 samples indicated that most of the radioactive minerals were contained in the heavy-mineral fractions (those greater than 3.3 specific gravity) of the samples. The minerals identified in the heavy-mineral fractions of selected samples are listed in table 2.

As shown in table 2, uranium in the form of metazeunerite, a hydrous copper-uranium arsenate (Frondel and Fleischer, 1952), was found in a trace amount in sample 4652 from the ore dump of the upper tunnel at the Konechney prospect. The metazeunerite very likely accounts for most of the radioactivity in the sample. The presence of this minor amount of metazeunerite may be indicative of considerably larger amounts at depths greater than could be detected by radioactivity traversing as the ore dump has been so highly oxidized and leached that even trace amounts of secondary uranium minerals would not be expected to occur in it. The same acid, oxidizing environment could account for the absence of both secondary and primary uranium minerals in the samples from ore dumps and surface outcrops elsewhere in the Russian Mountains. However, the metazeunerite in sample 4652 may merely be the remaining decomposition product of primary minerals including one or more uranium minerals that at one time occurred locally near the surface in veins or disseminated in the country rock. The source of the metazeunerite in this sample is probably the same as. for the metazeunerite in sample 1734 that was collected in the upper tunnel at the Konechney prospect by Wallace and Webber in 1944

The radioactivity of the remainder of the Russian Mountains samples is attributed chiefly to the presence of zirdon. Other minerals such as topaz, garnet, apatite, hematite, goethite, limonite, malachite, and perhaps some of the sulfides may contain trace amounts of uranium as an impurity and thus contribute slightly to the radioactivity of the samples in which they are found. However, none of the minerals from the area have been subjected to chemical tests for uranium.

Table 2. -Mineralogy ${ }^{1}$ of heavy-mineral fractions (those greater than 3.3 specific gravity) of selected samples from the Russian Mountains, Alaska

\begin{tabular}{|c|c|c|c|c|c|c|c|c|c|}
\hline \multirow[b]{2}{*}{ Minerals } & \multicolumn{9}{|c|}{ Estimated volume percent of minerals present in samples } \\
\hline & 4647 & 4648 & 4651 & 4652 & 4662 & 4664 & 4665 & 4666 & 4669 \\
\hline patite-- & & 1 & -..- & ---- & |---- & |---- & - & -1 & - \\
\hline senopyrite. & 45 & - & --.- & 1 & 3 & 40 & 60 & 80 & 50 \\
\hline Axinite----- & 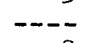 & 5 & --- & --- & 10 & --- & --- & $-\cdots$ & --- \\
\hline Azurite------ & $\operatorname{Tr} .^{2}$ & 2 & 5 & 10 & Tr. & Tr. & Tr. & --- & --- \\
\hline Biotite------ & --- & --- &.-- & --- & Tr. & -- & --- & -- & --- \\
\hline Chalcocite-- & --- & --- & --- & --- & --- & --- & --- & & $-\cdots$ \\
\hline Chalcopyrite--. & Tr. & --- & 10 & $\operatorname{Tr}$. & Tr. & 20 & 2 & 8 & 2 \\
\hline Chlorite-- & --- & --- & --- & ---- & 2 & --- & --- & $-\cdots$ & --- \\
\hline Chrysocolla--- & --- & Tr. & 2 & Tr. & $-\ldots$ & --- & --- & --- & --- \\
\hline Cuprite--- & --- & $-\cdots$ & --- & --- & -- & --- & 10 & --- & --- \\
\hline Diopside------- & $\operatorname{Tr}$. & --- & --- & 2 & --- & $-\cdots$ & --- & --- & --- \\
\hline Epidote------- & $-\cdots$ & 3 & $-\ldots$ & $-\cdots$ & --- & --- & --- & -- & --- \\
\hline Galena--.-- & --- & --- & --- & $\operatorname{Tr}$ & Tr. & --- & --- & 1 & --- \\
\hline Garnet--.--- & 13 & $-\cdots$ & --- & --- & 1 & $-\cdots$ & -- & $-\ldots$ & -- \\
\hline Goethite--..-. & Tr. & 5 & --- & 35 & 1 & $-\ldots$ & --- & $-\ldots$ & --- \\
\hline Gold---------- & --- & --- & --- & --- & Tr. & --- & --- & $-\cdots$ & --- \\
\hline Hematite------- & 12 & Tr. & 75 & 6 & 19 & $-\cdots$ & $-\cdots$ & $t--$ & --- \\
\hline Hornblende----. & --- & 5 & --- & --- & $-\ldots$ & --- & --- & - & - \\
\hline Ilmenite--------- & --- & 65 & --- & $-\cdots$ & 30 & 3 & --- & -- & \\
\hline Limonite------- & 9 & --- & 1 & 30. & --- & 6 & --- & - & \\
\hline Magnetite-----.-- & --- & 1 & I' & --- & --- & Tr. & --- & Tr. & --- \\
\hline Malachite--.--.- & Tr. & 1 & 2 & 15 & 1 & 1 & 4 & 1 & \\
\hline Metazeunerite--. & --- & --- & --- & Tr. & --- & $-\infty$ & $\mid---$ & & \\
\hline Native copper--- & --- & --- & $-\ldots$ & --- & $-\infty$ & -- & 2 & $-\infty$ & -- \\
\hline Pyrite-1- & $\operatorname{Tr}$. & 1 & 1 & $\operatorname{Tr}$. & 5 & 30 & 1 & $\operatorname{Tr}$. & \\
\hline Pyrrhotite--no & --- & 5 & 3 & 1 & 5 & Tr. & 1 & 2 & Tr. \\
\hline quartz-- - - & 1 & --- & $-\cdots$ & --- & --- & -- & 20 & --- & --- \\
\hline Rock minerals ${ }^{3}$ & --- & --- & --- & --- & 20 & --- & -- & L & --- \\
\hline Scheelite-1- & --- & $-\cdots$ & --- & $\operatorname{Tr}$ & Tr. & $-\cdots$ & --- & $-\cdots$ & --- \\
\hline Scorodite-- & --- & --- & --- & $-\cdots$ & --- & --- & $-\cdots$ & I-- & 44 \\
\hline Sphalerite--.-.-- & $--\cdot$ & --- & --- & ---- & --- & --- & $-\cdots$ & 2 & -- \\
\hline Topaz $-1-1$ & --- & --- & $-\cdots$ & Tr. & $-\cdots$ & $-\infty$ & --- & $-\cdots$ & - \\
\hline Zircon- & $\operatorname{Tr}$. & 5 & $\operatorname{Tr}$. & $\operatorname{Tr}$ & 1 & $\operatorname{Tr}$ & $-\cdots$ & -- & -- \\
\hline
\end{tabular}

\footnotetext{
${ }^{1}$ By W. S. West and J. J. Matzko.

${ }^{2}$ Tr.-trace.

${ }^{3}$ Mostly feldspar, quartz, and hornblende.
} 


\section{Marshall area}

Geology

The geology of the Marshall area has been described by Harrington (1918) and is shown on plate 2.

The rocks in the Marshall area include upper Carboniferous greenstone and upper Cretaceous argillites, conglomerates, sandstones, and shales intruded by soda granite, quartz diorite, diorite, and dacite of Tertiary or possibly in part early Mesozoic age. The intrusive rocks formed stocks and dikes. Some of the conglomerates, sandstones, and shales have locally been metamorphosed into quartzites and slates. Both barren and mineralized quartz veins, probably genetically related to the igneous intrusives, are common in the upper Carboniferous and Upper Cretaceous rocks. Late Tertiary or Quaternary basaltic lava flows occur south of Spruce Creek and in the vicinity of Russian Mission. Unconsolidated Quaternary deposits are found throughout the area and include the residual mantle or rock and soil on the higher hills and slopes, the gravels, sands, and silts of the terraces and lower hills, and the alluvium along the stream courses and in the lowlands of the Yukon River.

\section{Placer and lode deposits}

Placer-gold mining has been done on Disappointment and Elephant Creeks, tributaries to Wilson Creek, on Wilson Creek, and on Willow Creek, a tributary to Spruce Creek. Minor amounts of platinum occur in the concentrates from Wilson and Willow Creeks. The only active placer mining during 1952 was on Willow Creek.

A number of gold-lode claims have been staked in the Marshall area, but very little development work has been done on most of them. Freemilling gold is reported from quartz veins near the head of Edgar Creek, a west tributary to the Kuyukutuk River. Native gold, calcite, pyrite, galena, and molybdenite occur in quartz veins on a group of claims near the head of Willow Creek. Some of the veins contain a small amount of chalcopyrite.
This deposit is called the Arnold lode (sample localities 4659 and 4660 , pl. 2). The country rock is greenstone which in places shows strong pyritization. Development on the Arnold lode consists of prospect trenches and pits. One vein, 6 inches to 1 foot in width, has been traced along its strike for more than 100 feet by a series of trenches. A number of other veins have been exposed by opencuts elsewhere on this property. Mineralization similar to that of the Arnold lode occurs in quartz veins in the bank of the Yukon River at Marshall.

The formation of the quartz veins as well as the mineralization of the veins and in some cases the impregnation of the wall rocks are probably consequent to the intrusion of the granite stocks and dacite dikes.

\section{Radioactivity and mineralogic studies}

Systematic multiple flight-line radioactivity traverses were made with a U. S. Army L-19 reconnaissance plane over the divide between Wilson and Spruce Creeks and over Pilcher Mountain in the Marshall area. A single flight-line airborne traverse was made upstream along the Yukon River from Marshall via The Landing, Tkuak, Toklik, Kakamut, Akahamut, and Russian Mission to Kako Creek. In addition part of the highlands and bluffs along the Yukon River were traversed enroute from Holy Cross to Marshall and return.

Radioactivity traversing on foot and the collecting of rock and mineral samples were confined to the divide between Wilson and Spruce Creeks in the vicinity of Disappointment, Elephant, and Willow Creeks.

No significant radioactive deposits were discovered by radioactivity traverses.

The locations of the samples collected in the Marshall area are shown on plate 2. Equivalent uranium analyses of 7 unconcentrated samples are given in table 3 .

As shown in table 3 , no samples contained more than 0.001 percent equivalent uranium. The slight amount of radioactivity in samples 4657 and 4654 probably is caused by primary accessory minerals in the

Table 3.-Equivalent uranium analyses of samples from the Marshall area, Alaska

\begin{tabular}{|c|c|c|c|}
\hline $\begin{array}{c}\text { Sample } \\
\text { no. }\end{array}$ & Location & Type of material & $\left(\begin{array}{c}\mathrm{eU}^{1} \\
\text { percent })\end{array}\right.$ \\
\hline $\begin{array}{l}4657 \\
4654 \\
4655 \\
4656 \\
4659 \\
4660\end{array}$ & $\begin{array}{l}\text { Placer workings, Disappointment Creek } \\
\text { Ore dumps, upper opencuts, Arnold lode } \\
\text { Ore dumps, lower opencuts, Arnold lode } \\
\text { Ridge on left limit of Disappointment Creek }\end{array}$ & $\begin{array}{l}\text { Soda granite- } \\
\text { Dacite porphyry } \\
\text { Mineralized sedimentary } \\
\text { rocks. } \\
\text { Quartzite- } \\
\text { Quartz veins } \\
\text { Quartzite }\end{array}$ & $\begin{array}{r}0.001 \\
.001 \\
.001 \\
.001 \\
.001 \\
.001 \\
.001\end{array}$ \\
\hline
\end{tabular}

\footnotetext{
${ }^{2}$ Equivalent uranium.
} 
igneous rocks. Because of the low equivalent uranium content of the samples, only a very few mineralogic determinations were made. Mineralogic studies were made of the mineralized quartz vein samples from the A rnold lode, the most important lode deposit known to occur in the area. The minerals present in the heavymineral fractions (those greater than 3.3 specific gravity) of two samples from the Arnold lode are as follows:

Concentrations of heavy minerals in quartz veins from the Arnold lode, Marshall area, Alaska

\begin{tabular}{|c|c|c|c|}
\hline \multicolumn{2}{|c|}{ Sample 4659} & \multicolumn{2}{|c|}{ Sample 4660} \\
\hline Minerals & $\begin{array}{c}\text { Estimated } \\
\text { percent }\end{array}$ & Minerals & $\begin{array}{c}\text { Estimated } \\
\text { percent }\end{array}$ \\
\hline Limonite--.-.-- & 45 & Limonite--.---- & 60 \\
\hline Pyrite--..-... & 25 & Pyrite-...- & 28 \\
\hline Hematite-..... & 10 & Magnetite-..... & 5 \\
\hline Malachite-...-. & 6 & Malachite...... & 3 \\
\hline Galena-..-- & 6 & Wulfenite...... & 2 \\
\hline Anglesite-...- & 3 & Hematite-...... & 1 \\
\hline Barite? -...- & 2 & Anglesite-...-. & 1 \\
\hline Wulfenite-..... & 1 & Galena & $\operatorname{Tr}$ \\
\hline Pyrrhotite----- & 1 & Scheelite--..-- & $\operatorname{Tr}$. \\
\hline Magnetite-....- & 1 & Chalcopyrite--- & $\operatorname{Tr}$. \\
\hline Gold-n-n- & $\operatorname{Tr}$. & Azurite....... & $\operatorname{Tr}$ \\
\hline Chalcopyrite---- & $\operatorname{Tr}$. & & \\
\hline Azurite-...- & $\operatorname{Tr}$. & & \\
\hline Epidote-..- & $\operatorname{Tr}$. & & \\
\hline
\end{tabular}

No molybdenite was identified in the samples although it occurs in some of the quartz veins at this locality.

\section{Southern Kaiyuh Mountains}

\section{Geology}

The geology of the Kaiyuh Mountains has been described by Mertie (1937).

In the Kaiyuh Mountains undifferentiated metamorphic rocks of pre-Paleozoic or early Paleozoic age, including various types of sedimentary and igneous schists, phyllite, and slate, together with a minor proportion of chert and limestone and a group of rocks, probably of Carboniferous age, composed mainly of igneous rocks of greenstone habit, were intruded by granitic rocks of Mesozoic(?) age. Sandstone, shale, and conglomerate of Cretaceous age occur in the southwestern part of the Kaiyuh Mountains. Pleistocene and Recent alluvial deposits cover the bedrock deeply in the larger valleys and extend upstream into the uppermost headwater tributaries. Much of the bedrock in the hills is overlain by a mantle of residual and slope-wash deposits.

\section{McLeod molybdenite prospect}

The McLeod molybdenite prospect (fig. 2) was visited and described briefly by Robert Chapman (1945) of the Geological Survey.

The workings consist of several prospect pits and trenches that were excavated in 1942 by the late Ernest McLeod of Galena, Alaska. No additional work has been done since that time and the opencuts have slumped and become partly filled with rock debris. Consequently, the molybdenite-bearing vein in place is no longer exposed. The vein material consists of milky quartz containing scattered grains and clumps of molybdenite. Oxidation has altered much of the molybdenite to ferrimolybdite. An ore sample from one of the prospect pits is reported to have assayed 2 percent molybdenum. The vein appears to strike approximately N. $60^{\circ}$ E. and occurs in rhyolite porphyry having a fine-grained matrix and phenocrysts of plagioclase and biotite. A few fragments of greenstone were found in the rock mantle that covers the prospect and may have been derived from neighboring hilltops. The overburden on top of the saddle of the ridge where the deposit occurs is estimated to be about 4 feet in thickness. Vein float can be traced for a distance of about 250 feet on the saddle and several hundred feet down the slope.

\section{Radioactivity and mineralogic studies}

Airborne radioactivity traverses were made over the McLeod molybdenite prospect and surrounding area in a helicopter. Traversing on foot and the collecting of samples was restricted within the mineral claim boundaries.

No important radiation anomalies were found by either airborne or walking radioactivity traverses.

The equivalent uranium content of four samples collected in the area is given in table 4.

As shown in table 4, the equivalent uranium content of the samples ranges from less than 0.001 percent for the mineralized quartz vein material to 0.003 percent for the rhyolite porphyry.

Mineralogic determinations of samples 4670 and 4673 were made. The minerals present in the heavy-mineral fractions (those greater than 3.3 specific gravity) of the two samples are as follows:

Concentrations of heavy minerals in two samples from the McLeod molybdenite prospect, southern Kaiyuh Mountains, Alaska

\begin{tabular}{|c|c|c|c|}
\hline \multicolumn{2}{|c|}{ Sample 4670} & \multicolumn{2}{|c|}{ Sample 4673} \\
\hline Minerals & $\begin{array}{c}\text { Estimated } \\
\text { percent }\end{array}$ & Minerals & $\begin{array}{l}\text { Estimated } \\
\text { percent }\end{array}$ \\
\hline $\begin{array}{l}\text { Goethite---- } \\
\text { Molybdenite- } \\
\text { Limonite-- } \\
\text { Pyrrhotite-- } \\
\text { Ferrimolybdit } \\
\text { Pyrite-- }\end{array}$ & $\begin{array}{r}65 \\
20 \\
6 \\
4 \\
3 \\
2\end{array}$ & $\begin{array}{l}\text { Pyrite- } \\
\text { Pyrrhotite- } \\
\text { Zircon- } \\
\text { Goethite- } \\
\text { Magnetite- } \\
\text { Tourmaline-. }\end{array}$ & $\begin{array}{r}60 \\
20 \\
10 \\
7 \\
2 \\
1\end{array}$ \\
\hline
\end{tabular}

The iodide-light mineral fraction (2. 8 to 3.3 specific gravity) of sample 3673 contained about 97 percent biotite with pleochroic halos. Negative results were obtained from a flux test for uranium on the biotite.

The mineralogic analysis of sample 4673 indicates that most of the radioactivity of the rhyolite porphyry bedrock at the McLeod molybdenite prospect probably is due to the presence of the accessory mineral zircon. 
Table 4.-Equivalent uranium analyses of samples from the McLeod molybdenite prospect, southern Kaiyuh Mountains, Alaska

\begin{tabular}{|c|c|c|c|}
\hline $\begin{array}{c}\text { Sample } \\
\text { no. }\end{array}$ & Iocation & Type of material & $\begin{array}{c}\mathrm{eU}^{1} \\
\text { (percent) }\end{array}$ \\
\hline 4670 & Ore dump, pit on hill slope & $\begin{array}{l}\text { Mineralized quartz } \\
\text { veins. }\end{array}$ & 0.001 \\
\hline 4671 & Trench on saddle-..-- & $\begin{array}{l}\text { Mineralized rhyolite } \\
\text { porphyry. }\end{array}$ & .003 \\
\hline $\begin{array}{l}4672 \\
4673\end{array}$ & 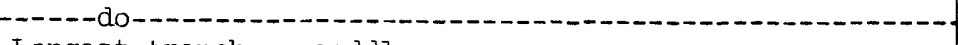 & Greenstone - & .002 \\
\hline
\end{tabular}

${ }^{1}$ Equivalent uranium.

\section{CONCLUSIONS}

Radioactivity reconnaissance in the Russian Mountains, Marshall area, and the McLeod molybdenite prospect in the southern Kaiyuh Mountains failed to reveal the occurrence of a commercial uranium deposit.

Although there appears to be no possibility that an important uranium deposit could occur at the localities studied in the Marshall area and southern Kaiyuh Mountains, it would be unwise to eliminate the Russian Mountains from consideration as a possible source of uranium because of the physical conditions that prevail at the surface and because time limitations did not permit a thorough investigation of the entire mountain area.

The discovery of only trace amounts of metazeunerite in samples from the ore dump and in the upper adit at the Konechney prospect and its complete absence in other samples from surface outcrops and ore dumps having highly acid, oxidizing environments does not necessarily mean that this secondary mineral was not more abundant and did not have a more widespread occurrence near the surface at one time. Metazeunerite is known to be at least slightly water-soluble and readily leached by sulfuric-acid rich waters. Leaching of the surface outcrops and ore dumps could also account for the absence of primary uranium minerals from which the uranium in the metazeunerite may have been derived. Even though secondary uranium minerals form under a great variety of conditions and may show no apparent relation to primary uranium minerals, the small amount of metazeunerite that has been found in the Russian Mountains may be indicative of larger amounts of secondary uranium minerals at greater depths which in turn may grade downward into zones of unaltered primary uranium oxides.

Additional prospecting or a detailed investigation with more sensitive radioactivity equipment might assist in revealing the source of the metazeunerite and lead to the discovery of other more significant occurrences of uranium minerals in the Russian Mountains.

\section{LITERATURE CITED}

Chapman, R. M. , 1945, Molybdenum prospect in the southern part of the Kaiyuh Hills, Alaska: U. S. Geol. Survey Press Release, 1 p. [April 12, 1945.]

Frondel, J. W., and Fleischer, Michael, 1952, A glossary of uranium-and thorium-bearing minerals: U. S. Geol. Survey Circ. 194.

Harrington, G. L. , 1918, The Anvik-Andreafski region, Alaska: U. S. Geol. Survey Bull. 683.

Maddren, A. G., 1915, Gold placers of the lower Kuskokwim, with a note on copper in the Russian Mountains, Alaska: U. S. Geol. Survey Bull. 622 .

Mertie, J. B., Jr., 1937, The Kaiyuh Hills, Alaska: U. S. Geol. Survey Bull. 868-D, p. $145-178$.

\section{UNPUBLISHED REPORT}

Moxham, R. M., 1950, The occurrence of zeunerite in the Russian Mountains, Alaska: U. S. Geol. Survey Trace Elements Inv. Rept. 57-D. 